DOI: 10.2478/RAE-2019-0029 Review of Artistic Education no. 182019 262-269

\title{
7. INTERACTIVE ACADEMIC EDUCATION AND ITS IMPACT ON URBAN DEVELOPMENT - HISTORY AND CONTEMPORANEOUSNESS
}

\author{
Bard Bajçinovci, Uliks Bajçinovci, Bujar Bajçinovci ${ }^{283}$
}

\begin{abstract}
Education for urban development is a process with a primary role to preserve and use of environment, to manage spatial planning and urban development as a whole holistic system. In relation to education for sustainable development, creativity of urban planning and design can significantly improve quality of life of their urbanites. Ergo, students and teachers are an epic symbiosis in a process of teaching. Actually, this interaction can be more bonded and interdependent with high-tech didactic tools. The digital era has implemented in the education system new creative methods of learning, a new way style in schooling. The new turn of the century began a crucial activity for the city of Prishtina in terms of urban, demographic and education phenomena. The study and aim of this paper are to examine the teaching process, with the focus on creativity of interactive education. The research methods consist of empirical observation, and direct observation of teaching methods. Findings indicate that through an informal meeting places for interactive education, the teaching process in architectural studies can bring more: sustainable development and awareness of space, a didactic process which bonds multidimensional threads between students and teachers. Research concludes that uniform old teaching platform, cannot respond to all specific issues faced by students in this globalization era. Therefore, new teaching strategies must involve creativity of interactive education.
\end{abstract}

Key words: Education, Urban, Art, Academia, Interactive

\section{Introduction}

The Faculty of Arts at the university of Prishtina are founded from the Academy of Art, which was established by the Assembly of Kosovo in 1973. The Academy started working on of the academic year 1973/74, and in the timeline of development in the academic year 1986/87, the Academy was transformed into the Faculty of Arts, with the title Faculty of Arts in Prishtina. In this context, the establishment of the Academy and later of the Faculty of Arts was the coronation of the many years of efforts of the pioneers of figurative, musical, and dramatic arts. Currently, the Faculty of Arts has three Departments: Department of Figurative Arts, Department of Music, Department of Dramatic Arts. So far, at the Faculty of Arts have graduated more than 900 students in Albanian language. Furthermore, in the context of the history and the contemporaneousness of the artistic education, the interactive academic education is in great holistic process of unequivocal learning and academic

\footnotetext{
${ }^{283}$ Student, cand.MSc, UBT. Architecture - Spatial Planning, Prishtina, Kosovo, email: bb34218@ubt-uni.net, Student, cand.MSc, UBT. Architecture - Spatial Planning, Prishtina, Kosovo, email: ub35398@ubt-uni.net, Associate Professor PhD., University of Prishtina, Kosovo, email: bujar.bajcinovci@uni-pr.edu
} 
advancement. Hence, what is the essence of this interaction? Surely, it is not a question with a simple answer. Actually, this interaction is more holistic and interdependent with contemporary education development, which in a whole learning experiences expands the concept of what is the education in first place.

In the field of urban development, introduction of contemporary education didactic tools has opened new possibilities for the artistic conception and creativity. "Cities are multiplex ecosystems driven by our daily life style, which directly reflect in our health, resources, economic, social and community services. They are open consolidated systems and extensive organisms with specific and multiplex metabolism that consume enormous amount of energy, generate excessive amount of waste, originate a sum of impromptu environmental phenomenon, and activities." 284 Cities can be environmentally percived as unique zones, and regionally different. Urban development is a process with a primary role to preserve the environment, to administer spatial planning and urban framework as a whole holistic system. In relation to teaching education for sustainability creativity of urban planning and design can significantly improve quality of life of their urbanites. In this context, the question is, what should be exactly the role of the interactive education. Thus, the whole didactic process remains open for creative expression in to the architectural schools. In this context, the question on what should be exactly the role of interactive education in design and teaching. Ergo, for the future perceiving of academia's role, it is crucial to be presented and implemented an unorthodox curriculum or a non-common way of transmitting knowledge.

Hence, we argue that new contemporary academia challenges should encourage a brand-new complementary study, using and developing new action research theories. strengthened with actions towards the exploitation of all resources, especially in nurturing cognitive development, in order to provide a better learning process. "Creativity of interactive education for sustainable urban development presents the necessity of evolving the metropolitan cities, presenting a much-needed holistic development for students, with a primary aim to preserve the environment, quality of life, and the whole system of social wellbeing." ${ }^{285}$ The other fundamental part on the interactive teaching creativity for students of architecture is the comprehension of the 'trend' and the background of its absorption in the teaching process. The intangible beliefs and impulse patterns of society over centuries have always had the strong causatum on values of what is a trend and what is ' $i n$ '. A great influence of unorthodox education in the art and architecture has over millennia emerged a development of unconventional ideas, which became a trend for society evolution, and academic liberties with new ways of methods for teaching. We argue that

\footnotetext{
${ }^{284}$ Bajçinovci, B., Jerliu, F. (2016). Challenges of Architectural Design in relation to Environment and Air Pollution. A Case study: Prishtina's first public parking garage. JOSHA. Freiburg. Germany.

${ }^{285}$ Bajçinovci, B., Jerliu, F. (2017). The Concept of "Modelarium" and its Impact on Creativity and Artistic Education. Review of Artistic Education no.14 2017.
} 
progress of technology in history has always had contrasting and strange encounters, hence, a breakthrough in progress has been made when great ideas was generated by lateral thinking ${ }^{286}$. According to the Hewett, in Curricula for Human-Computer Interaction, which stated: "Because human-computer interaction studies a human and a machine in communication, it draws from supporting knowledge on both the machine and the human side."287

\section{Materials and Methods}

The research presented in this paper reflects interactive methods in education for sustainable development, especially in architecture, creativity and innovation in academic teaching. Emphasizing interactive partnership learning methods in-between teachers and students. The research methods consist of empirical observation in academia, direct observation of teaching methods, and promoting contemporary interactive teaching methods. To perceive a clearer research data, exploring was made within the department of architecture, in the University of Prishtina, and in UBT - Higher Education Institution in the context of the possibilities for the improvement of the curricula's, within adapted and accredited academic frameworks.Creativity of interactive education for sustainability in architectural studies was explored through review of timeline of academic workshops, curricula's, and within studio researches of the students in Master programme of the department of architecture in the University of Prishtina, and UBT. Supplementary research data was provided from: studies of the urban structure of the University Campus, pioneering steps of interactive teaching for sustainable architecture, actions for preserving the local environment features, and attributes of spatial planning for the city of the Prishtina. With this paper the objective was to present a retrospective of history evolution of teaching methods in academia.

Furthermore, describing the teaching methods with the emphasis on creativity in education, which directly was reflected on actions for sustainable urban development. Moreover, there is a significant point to argue that the complexity and interactive teaching varieties of present situation cannot be fully described, without multidimensional, and transdisciplinary academic discourses. ${ }^{288}$ In terms of integration, an integrated process of organizing partnership into a functional system is a system that requires new solutions for problems, nurturing for adapting and evolving strategies. Integrated framework process implies partnership between students and teachers, with clearly identified priorities, which were in the process explored in enough qualitative iterations, seeking for the best solutions for the academic and professional dilemmas and problems. Many authors and research studies, claim that the

\footnotetext{
${ }^{286}$ De Bono, E. (2015). Lateral thinking, Creativity step by step. Harper Colophon; Reissue edition.

${ }^{287}$ Hewett, T. et al. (1992-1996). ACM SIGCHI Curricula for Human-Computer Interaction.

${ }^{288}$ Salite, I. (2009). Teachers perspectives on learning programs design for sustainability: The Latvia experience. Proceedings of the International conference citizenship, Multiculturalism, Cosmopolitanism. Nicosia, University of Cyprus.
} 
iteration is the key to understand the complexity of the cognitive process ${ }^{289}$ indicates that the iterative process, the application of simple rules, is at the heart of the mysterious ability of nature, in the production of multiplex phenomena and processes. Iterations of the "structure, function, and process in a given context would examine assumptions and properties of each element in its own right, then in relationship with other members of the set. Subsequent iterations would establish validity of the assumptions, then compatibilities and/or conflicts are identified and dissolved." 290

Dissolving conflicts may require re-conceptualization of the variables involved, finally, successive iterations will produce an integrated holistic solution. Successive iteration would output a greater awareness and more analogous to the nature of the whole. Further, these iterations, then, are like a reverse loupe through which we see the system we are trying to understand as a working part of successively bigger picture as presented in Figure 1.

Figure 1. Complexity of iterative model: Actions to exploit transdiciplinarity on teaching for sustainable development processes. (Gharajedaghi, 2006; Baj̧̧inovci, 2018).

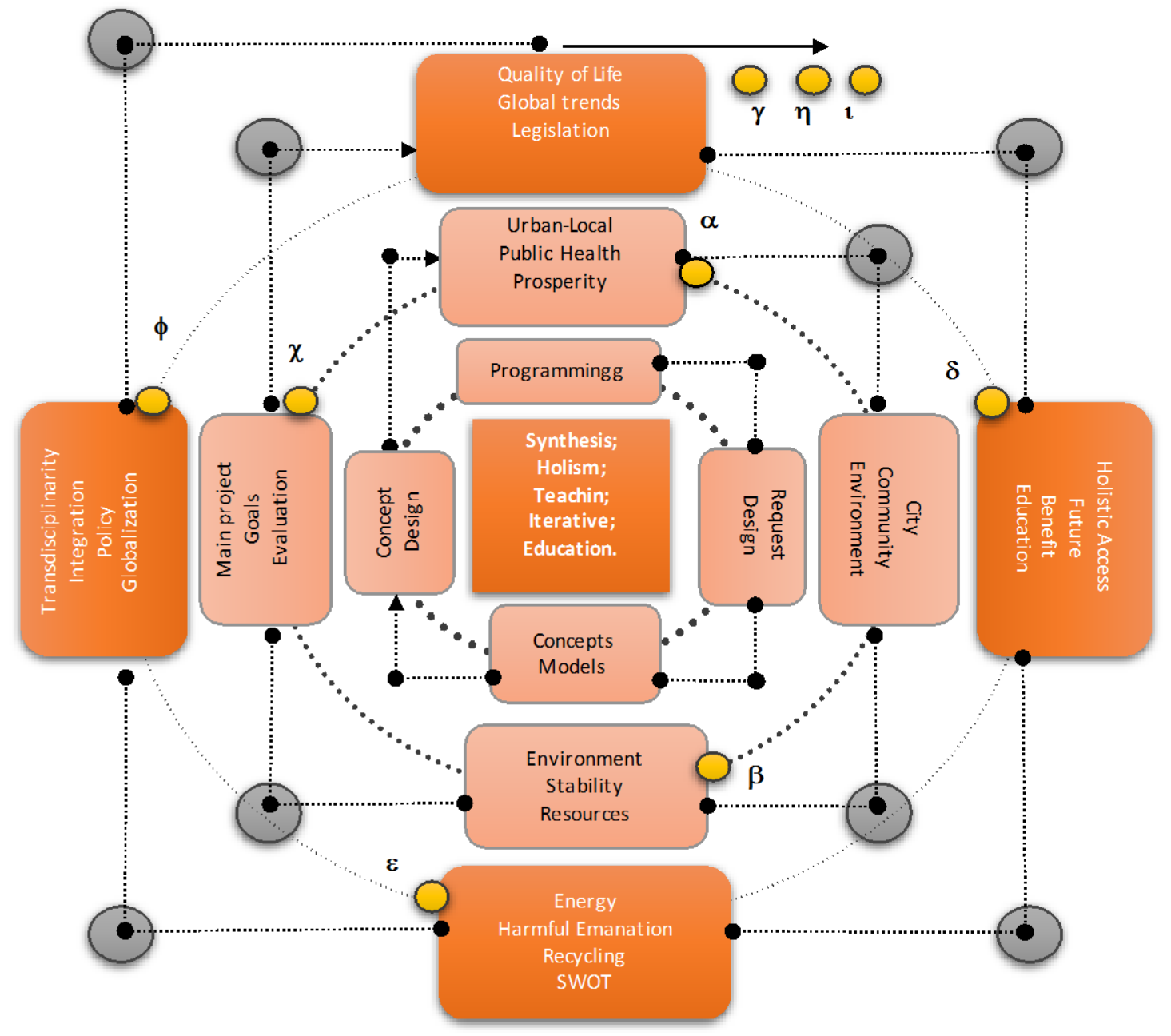

${ }^{289}$ Wolfram, S. 2002. A New Kind of Science. http://www.wolframscience.com/nksonline/toc.html, 2018.
${ }^{290}$ Gharajedaghi, J. (2006). Systems Thinking. Managing Chaos and Complexity. Elsevier. 
According to the result presented in Table 1, there is a lack of variety of courses in organization of the study programs, therefore we need a substantial rethinking of what we have to offer as an attractive curriculum.

Table 1. Students satisfaction with current study programme. (Eurostudent.eu/113, 2016; Bajçinovci, 2018).

\begin{tabular}{lllll} 
& $\begin{array}{l}\text { (Very) } \\
\text { Well }\end{array}$ & Fairly satisfied & $\begin{array}{l}\text { (Some) } \\
\text { Dissatisfied }\end{array}$ & Total \\
\hline & percent & percent & percent & percent \\
\hline 1. Quality of teaching & 48.9 & 33.5 & 17.6 & 100 \\
\hline $\begin{array}{l}\text { 2. Organization of } \\
\text { studies }\end{array}$ & 41.6 & 31.4 & 27 & 100 \\
\hline 3. Variety of courses & 26 & 23 & 51 & 100 \\
\hline 4. Study facilities & 38.6 & 23 & 38.4 & 100
\end{tabular}

\section{Discussions}

Current issues of improving the teaching quality and the introduction of completely new education concepts, demands a new fundamentally approach of integrated and holistic engaging for higher education ${ }^{291}$, into a creative teaching to respond to a new contemporary challenges. The process of integrating similar teaching fields aims to resolve all possible attributes of the research problem, so that any decision in the design process has to identify as many diversities of the creativity actions. The holistic process is associated with activities of all parties involved in the project, with objective to transform the nature of teaching, hence, to adopt and adapt, a new approach in solving urban sustainable development dilemmas on presented problem with unique attributes. "Education, of course, is always based on what was. Education shows you what has been and leaves you to make the deduction as to what may be. Education as we pursue it cannot prophesy, and does not."292

The art and architectural design has always been a pioneer of social change on basis of what is called the trend and contemporary. In terms of quality of life, the integrated process of cooperation between students and teachers ${ }^{293}$, will try to find the best result available for specific and unique problem, given the fact that never before as today, we have multifunctional and complementary studies as a result of the globalization, trend, strengthened with technology development. Therefore, those phenomena can realistically do impact on the global labour market, and in time seriously affect the global economics. So, a whole global networked system is holistically interacting with a wide subsystem that forms international labor market. Hence, "to the students stand a new contemporary challenge where student must be proactive key participant of

\footnotetext{
${ }^{291}$ Iliško, D. (2005). Pedagogical challenges for implementing holistic curriculum in Latvia. Journal of Teacher Education and Training

${ }^{292}$ Wright, Lloyd, F. (1955). https://christen.community.uaf.edu/2013/05/26/frank-lloyd-write-on-education/

${ }^{293}$ Iliško, D. (2007). Teachers as agents of societal change. Journal of Teacher Education for Sustainability
} 
future pedagogy. This visionary and contemporary academic framework must also be encouraged and implemented in Kosovo universities." 294

\section{Urban Development}

Spatial and urban development of the city Pristina, chronologically, it's important to evident the actions of spatial and urban planning:

- Pristina's development plan, (1937). Included the area of 192.72 ha and was programmed for population of 16,000 inhabitants;

- The second development plan, (1948). No trace of the existence of this documentation;

- General urban design, (1953). The timeline of spatial plan was up to 1980, planned for 50,000 inhabitants in the area of 950 ha;

- Directive plan for traffic and city dedicated zones, (1967). With action plan for 100,000 inhabitants;

- In 1969, the directive plan for city dedicated zones, was replaced by General Urban Plan;

- The overall urban plan and spatial development plan in 1988, approved for the timeline to year 2000, considering for 225,000 inhabitants.

The last two decades, have brought a variety of phenomena for the city of Prishtina, primarily demographic, social, academic, environmental and political challenges. "According to the estimate of the OSCE (Extrapolated level growth of former population in Kosovo 2\%/yr.), city of Prishtina in 2000 had 545,477 inhabitants. $" 295$ Thus, there are persistent institutional activities and municipal actions on the strategic development plans for the city. The new millennium began with crucial activities for Pristina, in terms of demographic and urban development. The city is experiencing a multiplex change in all possible social fields. Being the capital city of Kosovo, in a very short time the population of Prishtina has nearly doubled, adding every day approximately another $30 \%$ of the population coming in the city for work, possible settlement, and migration. ${ }^{294}$ "The future art public won't be a simple passive receiver, easy to manipulate, but, through a harmonious development of the soul functions and of the intellectual abilities, it will be able to develop its own creative, response and selection capacities for the messages coming from the social environment, messages that can distort the perception of reality and of internal representations." 296

\section{Conclusions}

The actual state of education requires specific contemporary methods, especially when the situation is directly linked to the quality of teaching and future challenges of the labor market. Hence, formally fulfilling legal academic

\footnotetext{
${ }^{294}$ Bajcinovci, B. (2018). Creativity of Interactive Academic Education for Sustainable Urban Development, JOSHA. Freiburg. Germany.

${ }^{295}$ Municipal of Prishtina, 2004.

${ }^{296}$ Pașca, Eugenia Maria. (2016). Variables and Constants in the curriculum for the music specializations of the Romanian University Education. Review of Artistic Education no. 11-12 2016, pp. 253-262.
} 
standards, within adapted and accredited academic frameworks, cannot be expected to solve comprehensive and future challenges, associated with the development of technology, labor market, life style, and global world trend. ${ }^{294}$ Findings in this paper indicate that through interactive teaching methods as contemporary learning strategies strengthened with informal meeting places for education, can concurrently present a teaching strategy, by which can bring more conceptual awareness for interactive contemporary learning. Thus, one and the same, and moderately new education strategy, cannot respond to all specific issues faced by academia, and future labor market. Ergo, new teaching strategies must involve a new symbiosis, a brand new and more refining holistic system, as a response to less functional academic system actually. The current classic teaching methods, formally fulfilling academic, and legal standards, requires a serious approach of academia for the contemporary teaching methods. Unique city problems will require unique, and original solutions. The current degraded state of the environment and urban fabric requires immediate contemporary environmental actions strengthened with the reformed teaching methods.

\section{References}

1. Bajçinovci, B., Jerliu, F. (2016). Challenges of Architectural Design in relation to Environment and Air Pollution. A Case study: Prishtina's first public parking garage. Journal of Science, Humanities and Arts. Freiburg. Germany, DOI: $10.17160 /$ josha.3.7.254.

2. Bajçinovci, B., Jerliu, F. (2017). The Concept of "Modelarium" and its Impact on Creativity and Artistic Education. Review of Artistic Education no.14 2017. De Gruyter. DOI: 10.1515/rae-2017-0030.

3. Bajcinovci, B. (2018). Creativity of Interactive Academic Education for Sustainable Urban Development, JOSHA. Freiburg. Germany.

4. De Bono, E. (2015). Lateral thinking, Creativity step by step. Harper Colophon; Reissue edition. ISBN-10: 0060903252, ISBN-13: 978-0060903251.

5. Gharajedaghi, J. (2006). Systems Thinking. Managing Chaos and Complexity. Elsevier.

6. Hewett, T. et al. (1992-1996). ACM SIGCHI Curricula for HumanComputer

Interaction. http://www2.parc.com/ist1/groups/uir/publications/items/UIR-1992-11-ACM.pdf (accessed 30 december 2017).

7. EuroStudent. http://database.eurostudent.eu/113, (Accessed: August 2017).

8. Hewett, Baecker, Card, Carey, Gasen, Mantei, Perlman, Strong and Verplank. (1992)."ACM SIGCHI Curricula for Human-Computer Interaction". ACM SIGCHI.

9. Iliško, D. (2005). Pedagogical challenges for implementing holistic curriculum in Latvia. Journal of Teacher Education and Training, 5, 28-39. 
10. Iliško, D. (2007). Teachers as agents of societal change. Journal of Teacher Education for Sustainability, 7, 14-26. doi: 10.2478/v10099-009-0002-9.

11. Municipal of Prishtina, 2004.

12. Paşca, Eugenia Maria. (2016). Variables and Constants in the curriculum for the music specializations of the Romanian University Education. Review of Artistic Education no. 11-12 2016, pp. 253-262. DOI: 10.1515/rae-2016-0030 13. Salite, I. (2009). Teacherís perspectives on learning programs design for sustainability: The Latvia experience. Proceedings of the International conference Citizenship, Multiculturalism, Cosmopolitanism,November 3-4, 2008, Nicosia, University of Cyprus, Vol. 1, 145-158, ISBN 978-9963-9442-1-7. 14. Wright, Lloyd, F. (1955).

https://christen.community.uaf.edu/2013/05/26/frank-lloyd-write-on-education/, (Accessed: June 2018).

15. Wolfram, S. 2002. A New Kind of Science, http://www.wolframscience.com/nksonline/toc.html,(Accessed: June 2018) 